\title{
The Lions \& the Greatest Part: the Rule of Law \& the Constitution of Employer Power
}

Dr. Julian A. Sempill

DPhil (Oxon) BA/LLB (Melb)

Senior Lecturer, Melbourne Law School, The University of Melbourne

185 Pelham Street, Carlton, 3053, Victoria, Australia

Telephone: +61390355368

Email: jsempill@unimelb.edu.au

Words excluding footnotes: 11,709

Words including footnotes: 14,774

\begin{abstract}
On the limited government conception of the Rule of Law, it is axiomatic that the state may only act for the public good according to law, and not arbitrarily, on pain of forfeiting its authority. That axiom is a great legacy of the seventeenth and eighteenth centuries' anti-absolutist revolutions. The same period yielded another axiom, seldom noticed though nonetheless momentous. It is the belief, usually tacit, that the Rule of Law should not address the potentially arbitrary power of employers. This Article explores the origins of that axiom in the work of John Locke, one of the fountainheads of the limited government tradition. According to the way of seeing power that Locke propagated, there seems to be no reason to wonder whether the constitution of the modern employment relationship is hospitable to arbitrary power, in the limited government sense. Equally, there seems to be no point in asking whether the legitimacy of the employment relationship should depend upon its being constituted according to limited government constraints. However, as I demonstrate, such impressions are at odds with key moral and empirical features of Locke's own analysis. Those tensions represent a challenge not only for Locke's analysis, but also for the liberal Rule of Law project that Locke helped to found. It is a challenge that the tradition is yet to address.
\end{abstract}

Keywords Rule of Law; legal philosophy; constitutional theory; employment law

\section{The Lions \& the Greatest Part: the Rule of Law \& the Constitution of Employer Power}

\begin{abstract}
On the limited government conception of the Rule of Law, it is axiomatic that the state may only act for the public good according to law, and not arbitrarily, on pain of forfeiting its authority. That axiom is a great legacy of the seventeenth and eighteenth centuries' anti-absolutist revolutions. The same period yielded another axiom, seldom noticed though nonetheless momentous. It is the belief, usually tacit, that the Rule of Law should not address the potentially arbitrary power of employers. This Article explores the origins of that axiom in the work of John Locke, one of the fountainheads of the limited government tradition. According to the way of seeing power that Locke propagated, there seems to be no reason to wonder whether the constitution of the modern employment relationship is hospitable to arbitrary power, in the limited government sense. Equally, there seems to be no point in asking whether the legitimacy of the employment relationship should depend upon its being constituted according to limited government constraints. However, as I demonstrate, such impressions are at odds with key moral and empirical features of Locke's own analysis. Those tensions represent a challenge not only for Locke's
\end{abstract}


analysis, but also for the liberal Rule of Law project that Locke helped to found. It is a challenge that the tradition is yet to address.

Keywords Rule of Law; legal philosophy; constitutional theory; employment law

\section{Introduction: An Ambiguous Legacy?}

The limited government tradition of John Locke, James Harrington, Algernon Sidney, and the U.S. Founding Fathers is defined by a set of theses concerning the legitimacy of state power. According to the tradition, state power is illegitimate if it is not properly constituted by law. The proper constitution of power entails a certain relationship between law, power, and interests, expectations, and rights. That relationship obtains where holders of executive, judicial, and, perhaps, legislative power are legally obliged to give due weight to certain morally respect-worthy interests, expectations, and rights of those subject to power. Where due weight is given, the compliance of subjects is sought on terms that involve genuinely good reasons for cooperation. The resultant mode of rule, being legitimate, is worthy of the label 'authority'. ${ }^{1}$

Some of the tradition's adherents use the term 'the Rule of Law' as a convenient shorthand for their preferred way of constituting power. Some are also accustomed to drawing a contrast between the Rule of Law and what they call the 'rule of men'. The 'rule of men' is a state of affairs wherein power is constituted in a manner that permits, de facto or de jure, the 'arbitrary' exercise of power. Power is exercised arbitrarily, on the traditional view, where a powerholder seeks compliance without giving due weight to genuinely respect-worthy interests, expectations, and rights. ${ }^{2}$ It is a mode of rule that entails sheer power rather than authority.

Put differently, arbitrary rulers deny the moral equality of the ruled. Moral equality comprises a set of interrelated axioms concerning the status common to all adult humans just in virtue of their being adult humans. ${ }^{3}$ The first axiom-all humans are of equal worth-is respected when we treat others as bearers of respect-worthy interests, expectations, and rights. We deny the equal worth of others when we treat them as though they lack respect-worthy interests, expectations, and rights. A failure to give due weight to human rights is an obvious instance of such denial. ${ }^{4}$

The second axiom - equal liberty, ie, adults owe no natural duties of obedience-is denied when we seek the cooperation or obedience of others by resorting to whatever means seem effective, such as force or fraud, irrespective of whether there are good reasons for compliance. Power is properly exercised if powerholders impose only those obligations that a free person would have reason to obey. A free person has a reason to obey where the obligations in question, among other things, are consistent with due weight being given to genuinely respect-worthy interests, expectations, and rights. A person who seeks the

\footnotetext{
1 On the origins of the limited government Rule of Law vision, see: $\square$ For leading contemporary restatements, see: Allan, 2003; Allan, 2013; Dworkin, 1985; Dworkin, 1996; Dworkin, 1998.

${ }^{2}$ On the limited government tradition's conception of arbitrariness, see [], section V.

${ }^{3}$ Ibid, section IV. (i) All humans are of equal worth, and such worth is often contrasted with the supposed lesser worth of non-human animals or the inferior status of mere things. (ii) Adult humans' natural state is one of equal liberty, meaning that we owe no natural duties of obedience to any other adult(s). Put differently, there is no natural authority amongst adults. This is often defined by contrast with the natural reciprocal duties of parents and children. (iii) All humans are equally subordinate to impersonal moral criteria. In seeking to identify good reasons for obedience, we accept that we are constrained by criteria which have impersonal and objective force. (iv) No human has privileged access to the fundamental requirements of impersonal morality. Or, put differently, there is a presumption that most adult humans possess a faculty of reason that allows them to recognize, though perhaps not independently to discover, such requirements.

${ }^{4}$ For a discussion of moral equality as a key principle animating the tradition, see ibid, section IV.
} 
cooperation or obedience of others, but does not respect the axioms of moral equality, seeks to manipulate them, reducing such persons to the status of mere instruments, manipulanda.

The revolutions of the seventeenth and eighteenth centuries reconstituted state power. One of the revolutionaries' goals was to promote moral equality. The limited government tradition's Rule of Law vision played a key role in that project. According to that vision, we have a duty to establish and maintain a system of law, among other things, in order to (i) identify or create genuinely respect-worthy interests, expectations, and rights and (ii) hold to account certain power-holders should they fail to give those respectworthy things due weight when they exercise power over others. In other words, under the Rule of Law, the law is supposed to tell power-holders what is genuinely respect-worthy and to provide ways to encourage compliance should powerholders be inclined to ignore this information. ${ }^{5}$ That relationship between law, power, and respect-worthy things must apply to the executive and judicial branches, at the very least; for some, it ought to apply to the legislative branch as well. ${ }^{6}$

One sign of the tradition's success is the embodiment of the constitutional principles just described in a range of legal doctrines and practices as well as non-legally-binding customs or conventions. Consider, for example, English law's tort of misfeasance in public office. As Lord Steyn describes it, the:

rationale of the tort is that in a legal system based on the rule of law executive or administrative power 'may be exercised only for the public good' and not for ulterior or improper purposes. ${ }^{7}$

Similar principles are evident in U.S. law. For instance, Justice Marshall of the Supreme Court declared:

The government may only act fairly and reasonably.... When something as valuable as the opportunity to work is at stake, the government may not reward some citizens and not others without demonstrating that its actions are fair and equitable. And it is procedural due process that is our fundamental guarantee of fairness, our protection against arbitrary, capricious, and unreasonable government action. ${ }^{8}$

According to the Rule of Law's ontology, a legitimate state's nature is not such that it may do as it pleases, unless the positive law just happens at the relevant time to provide otherwise. A state is legitimate only if, among other things, its very nature is constituteddefined and limited ab initio-by the secure embedding of Rule of Law principles in the positive laws and conventions which define state institutions. According to those principles, the state is constitutionally, not merely contingently, (legally) incapable of being 'arbitrary, capricious, and unreasonable'. That is the meaning of constitutionalism according to the limited government tradition.

In a Rule of Law state, the law does not present itself as restraining the state's inherent, pre-legal power, as it would restrain a subject's inherent, natural liberty. Rather, in accordance with the Rule of Law's ontology, the law imagines that the state has no prelegal power, let alone natural liberty. The legitimate state is, instead, presented as a legal

\footnotetext{
${ }^{5}$ For an overview of the traditional conception's main elements, see ibid, section VII.

${ }^{6}$ See, e.g., Dworkin, 1996 and Allan, 2013. Compare, e.g., Alexander Hamilton in The Federalist No 84, 1788.

7 Three Rivers District Council v Governor and Company of the Bank of England (No. 3) [2003] 2 AC 1, p. 190 [hereinafter 'Three Rivers']. Lord Steyn is quoting Jones v Swansea CC [1989] 3 All ER 162, p. 186. Emphasis added.

${ }^{8}$ Board of Regents v Roth 408 US 564 (1972), p. 489 (Justice Marshall) [hereinafter 'BOR v Roth'].
} 
artifice, having only such power as the law grants it. ${ }^{9}$ So, legal principles requiring the state to 'only act fairly and reasonably' are not thought of as having been imposed on an agent otherwise entitled to exist and to be at liberty; such principles are, on the contrary, considered necessary conditions of the existence of state authority as such. In a Rule of Law state, it is axiomatic that at least executive and judicial officials must, as a matter of law, 'only act fairly and reasonably' on pain of forfeiting their authority. That axiom is a great legacy of the seventeenth and eighteenth centuries' anti-absolutist revolutions.

\subsection{The State Axiom}

The same period yielded another axiom, seldom noticed though nonetheless momentous. It is the belief, usually tacit, that the Rule of Law should not address the potentially arbitrary power of employers. An employer acts arbitrarily by exercising power in a manner that denies an employee's equal worth and equal liberty - that is, in a manner that denies moral equality. Moral equality is denied if an employer fails to give due weight to an employee's morally respect-worthy interests, expectations, and rights. Immediately preceding the passage just quoted, Marshall alludes to the possibility of 'private' arbitrary power existing, legitimately, alongside the Rule of Law state:

[I]t is now firmly established that whether or not a private employer is free to act capriciously or unreasonably with respect to employment practices, at least absent statutory or contractual controls, a government employer is different. ${ }^{10}$

The contrast drawn by Marshall is striking. In the English context, we find a yet more jarring account of apparently legitimate 'private' arbitrariness in Allen v Flood:

An employer may discharge a workman (with whom he has no contract), or may refuse to employ one from the most mistaken, capricious, malicious, or morally reprehensible motives that can be conceived, but the workman has no right of action against him. ${ }^{11}$

Of course, since Allen was decided, as Marshall acknowledges, legislators and judges have sometimes sought to 'control', or regulate, employer power. Nonetheless, at least in the Anglophone world, such measures have not reconstituted the underlying constitution of employer power; rather, they have been superimposed upon it.

The contrast between regulation and reconstitution is often overlooked. Yet, it is crucial to a proper understanding of the distinctiveness of the limited government tradition's Rule of Law project. It is also a key element in the argument advanced below. For these reasons, it is necessary to offer a brief explanation of the nature of the distinction and its relevance to the present inquiry.

\footnotetext{
9 Three Rivers, p. 236 (Lord Millett) Hence: '[e]very power granted to a public official...': ibid.

${ }^{10}$ BOR v Roth. Consider the following dictum of a US court, which employs the term 'arbitrariness' without the pejorative connotations it conveys in the context of state power: the 'arbitrary right of the employer to employ or discharge labor, with or without regard to actuating motives' is 'settled beyond peradventure': Blades, 1967, p. 1416, quoting Union Labor Hospital Association v Vance Redwood Lumber Co 158 Cal 551 (1910), p. 555. The doctrine of 'at-will employment', while no longer as common in practice, has retained a doctrinal presence in the United States common law: e.g., Weiler, 1990, ch 2, pp. 48-104 and for the 'efficiency' justification, pp. 58-60.

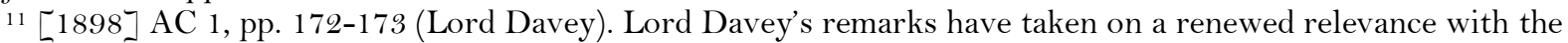
rise of so-called 'zero hours contracts', which apply to an estimated 1.4 million workers in the UK: Williams, 2014 .
} 


\subsubsection{Regulation \& Reconstitution}

Even when employer power is regulated, its underlying constitution remains substantially as articulated by Marshall: 'a private employer is free to act capriciously or unreasonably ..., at least absent statutory or contractual controls. ${ }^{12}$ The employer's 'freedom' includes, in effect, a license to use an employee as a mere means - an instrumentum vocale ${ }^{13}$ - for the achievement of the employer's ends. A duty of respect for the moral equality of employees - and, in particular, for their equal worth and equal liberty - is not treated as a constitutive feature of legitimate employer power. In other words, the constitution of the 'private' employer's power knows no equivalent to the 'fundamental guarantee of fairness', ${ }^{14}$ which Marshall saw as a constitutive element of the legitimate state's power.

Regulations-being merely superimposed-may be 'rolledback'. Such rollbacks amount to a restoration of what is regarded, in effect, as the employer's inherent or 'natural' prerogative power. When such rollbacks have been undertaken by neoliberal governments, the employer's freedom 'to act capriciously or unreasonably' has sprung back to life, as though it had been hibernating during the long winter of the welfare state. The modern regulatory project neither delegitimizes nor comprehensively reconstitutes the manipulative aspect of employer power: the underlying constitution of employer power is treated as legitimate-as a source of authority - even though it permits an employer to disregard the moral equality of those subject to that power. ${ }^{15}$

If employer power were reconstituted along anti-manipulative, limited government lines, it would no longer be regarded as belonging to the person designated 'employer'; it would, instead, be deemed to belong to an office. As employer power would belong to an office and not to its occupant, the exercise of power would not be treated as a matter of private right or prerogative. Rather, the exercise of power would be limited by an enforceable legal obligation to respect the proper ends of the office, which would include ensuring respect for the employee's moral interests, expectations and rights - on the assumption that they had been truly identified by, and enshrined in, law.

The office of employer, so transformed, would fall outside the current understanding of the categories 'private' and 'public'. ${ }^{16}$ It would no longer be plain, as it was for Marshall, that a 'government employer' must be 'different' from a 'private employer'. All employees would be constitutionally entitled-according to the constitution of the employment relationship — to 'feel secure and protected against arbitrary ... action'. ${ }^{17}$ The control of employer power would no longer be a matter of superimposing 'regulations' ad hoc on this or that aspect of 'private prerogative'. Indeed, the very notion of 'private prerogative' would be delegitimized and rendered incompatible with the essential nature of the office of employer. In other words, employer power would be reconstituted as a form of true authority rather than sheer power.

\footnotetext{
12 BOR v Roth. Emphasis added.

13 Arendt, 1999, p. 121.

14. BOR v Roth.

${ }^{15}$ I would assert that - there is not space here to offer an argument- the existence of English law's implied duty of trust and confidence does not require any substantial qualification of the point made in the main text: for a leading case, see Malik v Bank of Credit and Commerce International SA [1998] AC 20. However farreaching the implied duty may seem as a matter of abstract principle, as a matter of reality, it has not reconstituted the employment relationship along anti-manipulative lines: the duty does not impose a comprehensive and readily enforceable obligation to give due weight to the morally respect-worthy interests, expectations, and rights of employees.

${ }^{16}$ Further, the transformation would be likely to erode the morally incoherent distinction between 'civil and political' and 'social and economic' rights. For a discussion of the moral incoherence of the distinction, see Young, 2012.

17 BOR v Roth (Justice Marshall).
} 
This transformation in the very nature of employer power would emulate the seismic shift which occurred when the limited government idea drove the reconstitution of state power: state power was thenceforth to be understood as belonging to offices rather than to persons; and official power was to be constituted and limited by law in a manner designed to be thoroughly protective of moral equality. Defenders of absolutism once asserted that the 'kingdom' was the 'patrimony' of kings. ${ }^{18}$ Against this, the tradition's early modern adherents insisted that their political rulers did not have a 'right to the powers they exercised'. ${ }^{19}$ Rulers were instead to be granted powers. Furthermore, those powers were not to be treated as their property but were to be 'annexed to the office', ${ }^{20}$ which would be constituted and limited by law for the sake of protecting the moral equality of the ruled. Princely prerogatives were not to be regulated piecemeal, but were to be delegitimized and rendered incompatible with the very nature of the Rule of Law state.

The vision of transformed employer power described above is so remote from present conditions that it is difficult to form a mental picture of its broad outlines, let alone its everyday operation. Further, in an intellectual culture that urges quietism-but calls it 'pragmatism' or 'realism' - the vision is likely to seem quixotic: it is unlikely to be taken seriously by experts, and unlikely to find its way onto the public policy agenda of mainstream political parties, thinktanks or law reform bodies. But, then again, imagine how difficult it would have been for inhabitants of sixteenth century Europe or North America to picture, let alone to anticipate, the types of limited government arrangements which would begin to emerge in the centuries following their deaths.

In addition to the obstacles just described, there is also the difficulty posed by widespread reluctance to engage in inquiries that do not take for granted the maintenance of the present economic system. In the seventeenth and eighteenth centuries, the reconstitution of state power along limited government lines involved the transformation of the political system. Plainly, employer power could not be reconstituted as described above without transforming the present economic system, at least in substantial part.

Upon noticing this, some readers might be inclined to reject the line of inquiry that this Article seeks to open up. But to surrender to such an instinct, before the inquiry has really begun, would be to betray the critical spirit that is demanded by the limited government tradition's commitment to moral equality. Undoubtedly, that spirit has been poorly heeded in the past, as demonstrated by the attitude of the tradition's adherents to slavery, segregation, and other modern depravities. Properly heeded, however, it urges us to evaluate the constitutions of all forms of power, with a view to ensuring that they are sufficiently protective of moral equality. As Algernon Sidney wrote in the seventeenth century:

Laws and constitutions ought to be weighed, and whilst all due reverence is paid to such as are good, every nation may not only retain in itself a power of changing or abolishing all such as are not so, but ought to exercise that power according to the best of their understanding, and in the place of what was either at first mistaken or afterwards corrupted, to constitute that which is most conducing to the establishment of justice and liberty. ${ }^{21}$

This Article contends that the limited government tradition ought to weigh the axiom that is embedded in Marshall's distinction between two kinds of prerogative- on the one hand, legitimate 'private' prerogatives, and, on the other hand, illegitimate 'public' prerogatives.

\footnotetext{
18 Sidney, 1989, ch 3, \$43, 562.

${ }^{19}$ Ibid, ch 3, \$5, 346. A contemporary formulation of the idea is offered by Sir John Laws: 'the public decisionmaker has no individual rights in his role as such'; Laws, 1997, pp. 455, 466.

20 Sidney, 1989, ch 3, \$ 29, 497. For Kant on 'offices', see Ripstein, 2009, p. 191.

${ }^{21}$ Sidney, 1989, ch 3, \$25, 460.
} 
That axiom tells us that the limited government tradition's Rule of Law project is concerned exclusively with the danger of arbitrary state power. It implies that the tradition need not turn its attention to the potentially arbitrary power of employers. I will call this axiom the 'state axiom'.

\subsubsection{The cultural force of the state axiom}

The cultural force of the state axiom is evident if we consider how it operates as a background assumption in Rule of Law discourse. For example, it may imperceptibly prompt us to qualify what might otherwise be over-inclusive descriptions of contemporary Rule of Law practice. When a U.S. court declared that 'Discretionary power does not carry with it the right to its arbitrary exercise', it plainly did not intend to include non-state power, and its audience was unlikely to wonder whether it did. ${ }^{22}$ Or take E.C.S. Wade's statement that in A.V. Dicey's account of the Rule of Law: 'The emphasis is upon the limitations placed by the law on the exercise of power'; it is taken for granted that the 'power' concerned is state power. ${ }^{23}$

The state axiom may also be relied upon to cure potential ambiguity. For example, when Wade observes that during and after the Second World War there was a revival of interest in the rule of law' largely due to the 'contest' arising from 'the controlled use of property where the public interest competes with the wishes of the private owner', ${ }^{24}$ it goes without saying that such 'interest' was sparked by a concern to protect the private owner's 'economic field of liberty' ${ }^{25}$ not to place Rule of Law 'limitations' on the owner's 'wishes'. But what if the 'economic field of liberty' in question was in fact a potential source of arbitrary power?

In Dicey's day, in Wade's, and in our own, Rule of Law opposition to 'the exercise by persons in authority of wide arbitrary or discretionary powers' has almost always been directed at 'wide arbitrary or discretionary' state 'powers'. ${ }^{26}$ Because of the cultural force exerted by the state axiom-and its largely unexamined and unearned common sense status-strenuous labors are necessary simply to have it recognized that the state is not the only potential source of arbitrary power. Given that non-state power may also be afflicted by the denial of moral equality and therefore by arbitrariness, there is no obvious reason why the tradition's commitment to moral equality and its opposition to arbitrariness should be confined to the context of state power.

Recall the statement that 'Discretionary power does not carry with it the right to its arbitrary exercise': although the court risked exaggerating the actual reach of contemporary Rule of Law practice by not expressly confining the statement to state power, the court did not risk exaggerating the moral implications of the tradition's fundamental commitments; those implications reach beyond the state. For the sake of moral consistency, vigilance about moral equality and arbitrariness ought not to be confined to the state setting. It ought to extend to every context in which power over others is exercised. However, that is not to say that the Rule of Law is necessarily the right mechanism to promote moral equality and non-arbitrariness in every context. Nonetheless, even if, all things considered, there are good reasons to confine the Rule of Law to the state, those reasons need actually to be considered-explained and justified-rather than presumed. At present, the state axiom is a substitute for proper reflection on whether the Rule of Law's opposition to

\footnotetext{
${ }^{22}$ Schachtman v Dulles 225 F.2d 938 (DC Cir 1955) at 941, cited in Goodhart 1958, p. 956.

23 Wade 1961, p. cxv.

${ }^{24}$ Ibid xxix-xxx.

25 Ibid xxvii.

26 Ibid 188.
} 
arbitrary power ought to extend beyond the state. In what follows, I hope to encourage such reflection.

\subsection{This Article}

This Article explores the origins of the state axiom in the work of John Locke, one of the fountainheads of the limited government tradition. ${ }^{27}$ The Article thereby contributes to our understanding of the history of modern conceptions of the Rule of Law. According to the way of seeing power Locke propagated, there seems to be no reason to wonder whether the constitution of the modern employment relationship is hospitable to arbitrary power, in the limited government sense. Equally, there seems to be no point in asking whether the legitimacy of the employment relationship should depend upon its being constituted according to limited government constraints. However, I contend, those impressions are at odds with key moral and empirical features of Locke's own analysis. Those contentions are explained at length below. For now, it is enough to note the following.

According to Locke's political morality: powerholders may not seek compliance through manipulative means, which would include exploiting the economic dependence of subjects; power is only legitimate if a free person would have good reasons to consent to being under such power; in circumstances where experience teaches us that arbitrariness is likely, a free person would have good reason to refuse consent unless power is legally constituted so as to prevent arbitrariness. Locke rigorously applies those precepts of political morality to state power. However, he does not consider employer power in the same light-and this notwithstanding his own empirical account of employer power. According to one strand of Locke's empirical account, it is simply a fact of life that employers routinely achieve ascendancy over employees through the exploitation of the latter's economic dependence. Further, Locke appears to accept that employers may and will treat employees as mere instruments.

Given Locke's eminence within the tradition, his conclusion that its attention should be confined to state power is likely to have carried substantial weight among the tradition's adherents. Locke's influence may help to explain the existence and obstinacy of the state axiom. However, it is important to reiterate that the relevant way of seeing is not peculiar to Locke. On the contrary, it is a defining feature of the transition from the typically feudal to the typically modern way to 'systematise certain features' of the 'facts of power'. ${ }^{28}$ The observations I make about Locke's way of seeing therefore have implications that extend beyond his theory: they are a reflection on the prevailing, characteristically modern, way of seeing power. The tensions I identify in Locke's account represent a challenge not only for his theory, but also for the liberal Rule of Law project that Locke helped to found. It is a challenge that the tradition is yet to address.

\section{$1.3 \quad$ Employer power}

Before exploring those matters, it is necessary to explain what I mean by 'employer power'. As used here, the term refers primarily to the range of management powers sometimes collectively referred to as incidents of 'managerial prerogative', as well as to the powers an employer enjoys in connection with hiring and firing-eg, in connection with the specification of terms and conditions of employment. Such power is wielded by any

${ }_{27}$ For Locke's influence on English constitutionalism, see Pollock, 1922, p. 80. For Locke’s influence on U.S. constitutionalism, see McDowell, 2010, ch 3.

28 Milsom 1969, p. 8. 
relevantly situated manager, whether or not the concern is large or small, incorporated or unincorporated.

Employer power substantially derives its force from the fact that most actual or would-be employees, those primarily subject to the power, justifiably feel that their welfare depends to a great extent upon their being employed and, in turn, on the security and terms and conditions of their employment. Because of the feeling and reality of substantial economic dependence, such persons tend to submit to their employers, who therefore normally have a greater say in determining such security and terms and conditions. ${ }^{29}$

Further, the distribution of power characteristic of the capitalist employment relationship is simultaneously constituted, legitimized, and partly obscured by how the law treats it as the product of freedom of contract. This fiction continues to prevail as a matter of legal doctrine - at least in the Anglophone countries-notwithstanding widespread scholarly recognition that the legal constitution of internal power amounts to 'a command under the guise of an agreement', ${ }^{30}$ as well as the occasional acknowledgment of this by some of the law's highest officials. ${ }^{31}$ Like so many of his liberal heirs, Locke was ambivalent about these facts of modern life - or, to be more precise, about such facts as they appeared to him in their emergent, early modern forms; and for good reason. The relevant phenomena seem to point to a contradiction between two sets of widely held liberal commitments: a commitment to the modern property system, on the one hand, and a commitment to the principles of equal liberty and equal worth, on the other. Moreover, the facts invite the suspicion that the liberal Rule of Law project draws morally arbitrary distinctions between state and non-state sources of prerogative power.

\section{Ownership and jurisdictional power}

The transition from feudal to modern power relations saw jurisdictional power reposed exclusively in the state. ${ }^{32}$ One consequence of the transition was the eclipse of dominium, which was a formalized way of combining jurisdiction, property ownership, and relations of economic dependence and power. ${ }^{33}$ Dominium conferred upon lordship not only a measure of political authority (eg, the right to 'hold court and declare law'), ${ }^{34}$ but also a de jure authority to extract economic resources from the lord's subjects.

The relevant dimensions of the transition are captured by S.F.C. Milsom's way of trying to make dominium intelligible to modern readers. During feudalism, '[l] ordship and ownership, government and property, were not ... clearly distinct as they seem to us...': ${ }^{35}$

Lordship, the Latin dominium, is to us an ambiguous word, because to us the concepts of ownership and jurisdiction are distinct: to understand this starting-point, we must think away that ambiguity, and not try to resolve it. The rights of a great landowner were not over empty land but over the people who worked the land, or over inferior lords with rights over those people.

\footnotetext{
29 Max Weber provides a noteworthy sketch of this dimension of economic power: 'Formally, the market community does not recognize direct coercion on the basis of personal authority. It produces in its stead a special kind of coercive situation ... The sanctions consist in the loss or decrease of economic power and, under certain conditions, in the very loss of one's economic existence.' Weber c1922, v1, pp. 730-731.

30 Kahn-Freund 1949, p. 28.

${ }^{31}$ See main text below at $\mathrm{n} 49$.

32 On the legal dimension: Milsom 1969. On the capitalist 'differentiation of "spheres", especially the "economic" and the "political”, see Wood 1995, ch 1, pp. 19-48.

33 Wood 1995, ch 1, pp. 19-48.

${ }^{34}$ Berman 1983, p. 312.

35 Milsom 1969, p. 8. Wood 2008 p 22: 'With the rise of feudalism', the 'tension [between imperium and dominium] was resolved on the side of dominium, as the state was virtually dissolved into individual property.'
} 
Lordship was property, the object of legal protection from above, just as it was the source of legal protection for rights below. ${ }^{36}$

It is also important to note Milsom's observation that, 'Feudalism was not a system, or even an ideal, having fixed properties. Such definite ideas as the word connotes are the creation of lawyers and historians seeking to systematise certain features which the facts of power might produce in medieval society'. ${ }^{37}$ Although England remained substantially an agrarian economy when Locke wrote the two treatises, the process of reconceptualization and systematization of post-feudal facts of power was in an advanced stage. ${ }^{38}$ By Locke's time, 'the Latin dominium', was already 'an ambiguous word' in the way Milsom notices.

One of Locke's chief aims in the two treatises was to obliterate the vestigial political trappings of the feudal notion of dominium. He wanted finally to do away with the notions that 'governmental power, jurisdictional power' is dominium and that '[o]ffice is property'. ${ }^{39}$ Such views, Locke thought, provided succor to absolutism. Holders of jurisdictional power should not be entitled to treat their offices as property and their power over others as personal prerogatives. Property and political authority must be seen as distinct, and state power should be constituted so that it may only legitimately exist within certain limits. Such limits would ensure, among other things, that the state's subjects might securely enjoy their property — which, in time, would come to be seen as 'private' property.

So, Locke aimed 'to resolve' the 'ambiguity' spoken of by Milsom, and he wanted to do so in a way that would encourage his readers to see ownership and political authority as obviously distinct. According to this way of seeing power, the power over others conferred by private ownership, if it is noticed at all, is not seen as the kind of power that should trouble advocates of limited government. The people's property must be protected from state power by limited government measures; but the people do not require limited government protection from the power of property owners. Locke contributed to conceptualizing and systematizing certain emergent facts of modern power, shaping, among other things, our perception of the relationship between the Rule of Law and various sources of power.

\subsection{Permissible and impermissible governmental power}

There are tensions between Locke's empirical and normative accounts of the employment relationship. In order to illuminate them, it is useful to begin by considering how he distinguishes (i) between three kinds of permissible power over others, as well as (ii) between these kinds of permissible power and certain forms of impermissible power. ${ }^{40}$

\footnotetext{
${ }^{36}$ Milsom 1969, p. 88.

37 Ibid, p. 8.

38 Wood 1984.

39 Schuyler 1960, p. 151.

40 The table is a distillation of the categories Locke employs in Locke 1689b [hereinafter 'Treatises'].
} 


\begin{tabular}{|l|l|l|l|}
\hline & $\begin{array}{l}\text { Powers over others: } \\
\text { set (a) }\end{array}$ & $\begin{array}{l}\text { Powers over } \\
\text { others: } \\
\text { set (b) }\end{array}$ & $\begin{array}{l}\text { Powers over others: } \\
\text { set (c) }\end{array}$ \\
\hline & eg, jurisdictional power & eg, parental power & eg, just enslavement \\
\hline $\begin{array}{l}\text { may only be exercised } \\
\text { with consent }\end{array}$ & $\begin{array}{l}\text { may be exercised } \\
\text { without consent }\end{array}$ & $\begin{array}{l}\text { may be exercised } \\
\text { without consent }\end{array}$ \\
\hline $\begin{array}{l}\text { conventional (ie, exists } \\
\text { by agreement) }\end{array}$ & $\begin{array}{l}\text { occurs naturally, and } \\
\text { is justified by natural } \\
\text { law }\end{array}$ & $\begin{array}{l}\text { does not occur } \\
\text { naturally, but is } \\
\text { justified by natural law }\end{array}$ \\
\hline
\end{tabular}

The elements in column (a) combine with one another to form a set, as do those in each of column (b) and column (c) respectively:

- Jurisdictional power belongs to set (a): it entails power over others that may only be exercised with the consent of the governed, and it is conventional-ie, it exists by agreement rather than by nature. Such consent is necessary if moral equality between persons is to be maintained in the establishment and exercise of jurisdictional power. Locke holds that all adults are moral equals by nature, which implies, among other things, that no adult owes natural jurisdictional obligations to anybody else- they enjoy equal liberty. ${ }^{41}$

- Parental power belongs to set (b): it entails powers over children that may be exercised without consent, it occurs naturally, and it is justified by natural law so long as its proper limits are respected.

- Just enslavement belongs to set (c): it entails powers over others that may be exercised without the slaves' consent, and, although it does not occur naturally, it is justified by the law of nature. ${ }^{42}$

Outside these categories of permissible power lie various types of impermissible power over others. Unjust enslavement and absolutism are two cases addressed by Locke: they both involve the exercise of powers over others in a manner contrary to the law of nature, and they are conditions to which nobody may validly consent.

\subsection{Locke's account of the employment relationship}

Does the power exercised by employers over their economically dependent employees require the consent of the latter? Is it conventional or is it natural? How does such power stand in relation to the categories of permissible and impermissible power just identified?

If, in an attempt to respond to those questions, we study Locke's portrait of the employment relationship, we uncover a range of tensions and contortions. I would argue that the tensions and contortions are revealing: they are the price of seeking, in effect, to show that the incipient modern employment relationship is compatible with a commitment to moral equality. Locke does not set out explicitly to reconcile the employment relationship with his limited government vision. On the contrary, he does not openly

${ }^{41}$ Locke 1689b, Treatises, II \$54. Compare Cohen 1999, pp. 147, 149.

42 Farr 1986. 
acknowledge that, by his own lights, it would in fact make moral sense to evaluate employer power in limited government terms. However, his remarks on the employment relationship do seem to reflect a tacit desire to demonstrate that the relationship does not offend moral equality. On the one hand, Locke suggests that, in certain respects, the power wielded by any particular employer over any particular employee - for convenience, 'Employee $x$ ' and 'Employer $y$-belongs to set (a). The terms and conditions of such power are portrayed as the products not of nature but of a freely established agreement between the parties. Insofar as Employer $y$ appears to have secured the voluntary compliance of Employee $x$, the employer's power over the employee does not seem to entail disrespect for equal liberty, or any other aspect of moral equality. The power of Employer $y$ is therefore presented, implicitly, as belonging to set (a), one of Locke's categories of permissible power. Textual support for this can be derived from $\$ 85$ of the Second Treatise, in which Locke says that Employee $x$ is 'a Free-man' who 'gives the Master but a Temporary Power over him, and no greater than what is contained in the Contract between 'em'. ${ }^{43}$ On the other hand, however, on Locke's own empirical account of employer power, the two conditions which define set (a) - namely, consent and conventionality - tell only part of the story of how it has come to pass that Employee $x$ is obliged to obey the directions of Employer $y$.

\subsubsection{Consent}

Locke observes that the dependent economic status of employees means that employees must always serve at least some one employer:

...the greatest part of Mankind, who are given up to Labour, and enslaved to the Necessity of their mean Condition; whose Lives are worn out, only in the Provisions for Living.....all their whole Time and Pains is laid out, to still the Croaking of their own Bellies, or the Cries of their Children. ${ }^{44}$

Locke assumes that economic dependence and, in turn, servility are 'unavoidably' endured by 'a great part of mankind'-unavoidably because of what Locke terms 'the natural and unalterable State of Things in this World, and the Constitution of Humane Affairs', of which more below at Section 2.2.2.45 Locke appears to be saying that employer and employee are inter-related social categories that one occupies-in the employee's case, independently of one's will - according to whether one is a seller of labor or a buyer, which depends upon one's relationship to economic dependence ('Necessity'). ${ }^{46}$

According to Locke, Employee $x$ must have consented to serve Employer $y$, or else be deemed Employer $y$ 's slave. But he also implies that, in reality, Employee $x$ lacks the capacity to withhold consent from all employers. In the absence of such capacity, from Employee $x$ 's perspective, the distinction between service and slavery might feel as though it rested on a thin reed. If labor market conditions were such that service to Employer $y$ represented the only apparent source of subsistence, the juridical option of refusing to serve

\footnotetext{
${ }^{43}$ Locke 1689b, Treatises, II §85. Emphasis in original.

${ }^{44}$ Locke 1689a, Essay, bk IV, ch XX, \$2.

${ }_{45}$ Ibid. To be sure, Locke made these observations in order to make a point about intellectual obstacles facing those whose 'opportunities of knowledge and inquiry are commonly as narrow as their fortunes': ibid. But the epistemological significance of such remarks is not why they are germane to the present inquiry. The observations matter for present purposes because they suggest that Locke regarded the relationship of dependency-and-servility described in the main text as inevitable. I would like to thank one of the Journal's anonymous referees who highlighted the need to include this elaboration.

${ }_{46}$ This is analogous to Karl Marx's view that which 'class' one belongs to is determined by one's relationship to the means of production, ie, one's position in what he called the 'realm of necessity': Marx 1894.
} 
would be experienced as an unreal alternative. ${ }^{47}$ If it seemed to Employee $x$ that there were no other employers who would purchase Employee $x$ 's labor power, then so far as Employee $x$ was concerned, it would necessarily be Employer $y$. Being subject to 'Necessity', Employee $x$ would be compelled to serve Employer $y$, on Locke's own view of compulsion:

$[\mathrm{H}]$ e that forced a promise from me ought presently to restore it, i.e., quit me of the obligation of it; ... Nor does it alter the case to say, I gave my promise, not more than it excuses the force, and passes the right, when I put my hand in my pocket, and deliver my purse myself to a thief, who demands it with a pistol at my breast. ${ }^{48}$

Compare Justice H.B. Higgins's account of the law's questionable treatment of employer power:

The power of the employer to withhold bread is a much more effective weapon than the power of the employee to refuse labour. Freedom of contract under such circumstances is surely misnamed; it should rather be called despotism in contract ... the worker is in the same position as ... a traveler, when he had to give up his money to a highway man for the privilege of life. ${ }^{49}$

Compulsion would occur notwithstanding Employee $x$ 's possession of a juridical right to refuse to serve Employer $y$, which was not possessed by certain feudal economic inferiors. That is, of course, the distinctive plight of juridically 'free labor' under capitalism, the essence of the wage-relation that characterizes the domination of the working class by the capitalist class, according to Karl Marx:

[T] he worker, whose sole source of livelihood is the sale of his labour power, cannot leave the whole class of purchasers, that is, the capitalist class, without renouncing his existence. He belongs not to this or that capitalist but to the capitalist class, and, moreover, it is his business to dispose of himself, that is, to find a purchaser within this class..$^{50}$

On this view, employees labor under an informal but nonetheless potent obligation of necessity that enables their economic subjection by employers: ${ }^{51}$ Employee $x$, in effect, always owes tribute to a member of the class of employers. The worker's 'business' is 'to find a purchaser within this class', in satisfaction of what is effectively the worker's de facto but not de jure economic obligation to the 'whole class of purchasers'. The employers' business, by contrast, is to find employees whose labor power may be purchased. By bringing the labor power of Employee $x$ under his control, Employer $y$ has in effect

\footnotetext{
47 According to Wood, Locke observed that in his day demand for day-laborers exceeded supply. This may have led Locke to assume that servants would have a choice between masters: Wood 1984. However, as a matter of limited government principle, perhaps this shouldn't be sufficient; perhaps protection for moral equality shouldn't be contingent on labor market conditions; on one view, a legal obligation to respect moral equality should be constitutive of the relation itself. (A similar point could be made in relation to Locke's exhortation in favor of voluntary charitable giving as a way of relieving the needy state of economic inferiors.) As Locke places the distribution of economic resources 'out of the bounds of society, and without compact', and (reasonably) assumes 'an inequality of private possessions' (Locke 1689b, Treatises, II \$50), equality of bargaining power is neither a condition nor a feasible consequence of mere juridical equality.

${ }^{48}$ Locke 1689b, Treatises, II \$186, see also II \$176.

49 Justice Higgins: Federated Engine Drivers' and Firemen's Association of Australasia v Broken Hill Pty Co Ltd (1911) 5 CAR 9, p. 27 [hereinafter 'FEDFA v BHP Ltd'].

50 Karl Marx, Wage Labor and Capital quoted in Avineri 1968, p. 164.

${ }^{51}$ See also Weber c1922, vol 1, pp. 730-731.
} 
augmented the effective power ${ }^{52}$ at his disposal, ${ }^{53}$ as Locke himself implies in the following: ${ }^{54}$

The chief end of trade is riches and power, which beget each other. ... Power consists in numbers of men, and ability to maintain them. Trade conduces to both these [riches and power] by increasing your stock and your people, and they each other. ${ }^{55}$

Here Locke engages with developmental tendencies of certain facts of power in transition: ownership, now without the political trappings of dominium, more and more becomes an independent source of substantial power over others; ${ }^{56}$ the concentration of resource ownership creates the conditions of 'Necessity' under which employees must sell their labor time to employers. ${ }^{57}$

As economic dominance no longer depends upon de jure privileges and corresponding obligations, we can intelligibly speak — as some now do—of 'the privileged' in a society without 'privileges'. ${ }^{58}$ The transition from feudalism is marked in part by the displacement of de jure relations of economic power in favor of the kind of contractual employment relationship described by Locke. But the eclipse of feudal dominium does not bring about the emancipation of employees from the power of employers. On the one hand, Locke himself acknowledges that employers typically secure the subordination of employees by exploiting the latter's economic dependence. On the other hand, he obscures that dimension of the employment relationship by advancing a theory that encourages us to see only the parties' juridical equality. Locke's way of seeing the employment relationship anticipated, and perhaps contributed to, the way of seeing characteristic of liberal public philosophy's ${ }^{59}$ social vision. ${ }^{60}$

52 'Effective power' refers to simply what a person is capable of choosing to do or to refrain from doing. This sense of power Locke associates with an idea of freedom as the absence of external impediment: '...the Idea of Liberty, is the Idea of a Power in any Agent to do or forbear any particular Action, according to the determination or thought of the mind...': Locke 1689a, Essay, bk II, ch XXI \$8.

${ }^{53}$ Employer $y$ directs how the effective power of Employee $x$ is applied: Locke 1689a, Essay, bk II, ch XXI $\$ \$ 8$. Note that on Ripstein's account, Kant holds that a person's 'powers can be interfered with ... by usurping them... I usurp your powers if I exercise them for my own purposes, or get you to exercise them for my purposes.... I am like the despot who uses his office for a private purpose': Ripstein 2009, pp. 43-44.

${ }_{54}$ Consider how F.A. Hayek finesses this point: Hayek 1960, pp. 118-119.

${ }_{55}^{5}$ Quoted in Wood 1984, p. 32.

${ }_{56}$ Wood 1995, p. 208.

57 Neal Wood convincingly argues that Locke's conception of wage-labour was based on incipient English agrarian (not industrial) capitalism of which Locke was a keen observer: Wood 1984 generally, especially pp. 44, 85-92. When Locke used the term 'servant' in the Second Treatise, he had in mind principally the agricultural 'day labourer' (neither the 'servant in husbandry' (p. 42), nor 'token workers' (p. 42), nor domestic servants, nor the 'great men's menial servants' (p. 41)). As Wood explains, Locke writes about agricultural day labourers who 'were paid by the tenant for ... labor power during a fixed period of time' (p. 42). In my view, that Locke principally had in mind the agricultural day labourer when he spoke of 'servants' in the Second Treatise is evidenced by (i) the famous Turfs passage (Locke 1689b, Treatises, II §28), and (ii) his assumption that servants serve on a fixed term basis (which day labourers did) rather than on an open-ended basis (as domestic servants did). See, further, Cohen 1999, Waldron 1988, pp. 144-148, 225-232, Tully 1980, Macpherson 1962.

${ }_{58}$ On feudal privilege, Weber c1922, vol 1, p 843. Milsom 1969, pp. 8-11, 89-90.

${ }_{59}$ I am using 'public philosophy' in the sense employed in Sandel 1998.

60 The reading of Locke just offered contradicts James Tully's. According to Tully's view, Locke ruled out wage-labour on the ground of its ineradicable involuntariness, but held that the employment relationship is legitimate if the employee has the choice not to be an employee at all: Tully 1980, pp. 136ff. However, as has been pointed out, this appears to misread Locke: Wood 1984, pp. 89, 85-92; Cohen 1999, p. 164, note 7; Waldron 1988, pp. 144-148, 225-232. 


\subsubsection{Nature}

$\$ 85$ of the Second Treatise, which I quoted earlier, ${ }^{61}$ gives the impression that relations between Employee $x$ and Employer $y$ are a mere matter of agreement, and are therefore not natural, but rather conventional. However, as mentioned in the previous section, Locke describes the relations of economic dependence ('Necessity') that generate the power of employers over employees as 'the natural and unalterable State of Things in this World, and the Constitution of humane Affairs'. ${ }^{62}$

Further, at $\$ 77$ of the Second Treatise, Locke seems to place the employment relationship on the same plane as the more plausibly natural social relations of "parents and children', which belong to set (b) (ie, a natural relation that entails powers over persons which may be exercised without their consent):

God having made Man such a Creature, that, in his own Judgment, it was not good for him to be alone, put him under strong Obligations of Necessity, Convenience, and Inclination to drive him into Society, as well as fitted him with Understanding and Language to continue and enjoy it. The first Society was between Man and Wife, which gave beginning to that between Parents and Children; to which, in time, that between Master and Servant came to be added....63

The dependence of employees is seen as an element of 'the natural and unalterable State of Things in this World' partly because Locke's theory of property sees the concentration of economic resources as natural and unalterable. ${ }^{64}$ The partage of things, in an inequality of private possessions, men have made practicable out of the bounds of society, and without compact' thanks to the advent of money in the state of nature. ${ }^{65}$

\section{Tensions within Locke's way of seeing the employment relationship}

On Locke's account, the law of nature gives all 'men'66 moral equality with one hand, and deprives them of equal access to resources with the other. That leads to tensions in Locke's way of seeing the employment relationship. Locke holds that no employer can claim that Employee $x$ is required by nature, or birth, or law, to serve him and therefore has no choice in the matter; such a claim would be inconsistent with Employee $x$ 's moral equality. But, despite this, Locke acknowledges that employees are in a state of natural dependence on employers - and therefore in their thrall—by virtue of what might be called, adopting one of Locke's phrases, the 'Obligations of Necessity's7 arising from the 'the natural and unalterable' concentration of resources.

\footnotetext{
${ }^{61}$ See main text above at $\mathrm{n} 43$.

${ }^{62}$ Locke 1689a, Essay, bk IV, ch XX, §2.

${ }^{63}$ Locke 1689 b, Treatises, II $\$ 77$. Emphasis in original.

${ }^{64}$ Why natural? Locke holds that the distribution of property and the advent of money, which allows the transcendence of the 'spoilage condition', is 'given out of the bounds of society and without compact': Locke 1689b, Treatises, II \$50. See further, Macpherson 1962, pp. 208-210; Cohen 1999, p. 162. Why unalterable? Locke holds that the consent of owners would be required before an alteration may legitimately occur, and it is reasonable on Lockean premises to presume that owners would not consent to any far-reaching redistribution. ${ }^{65}$ Locke 1689 b, Treatises, II $\$ 50$.

${ }^{66}$ I use 'man' and 'men' and masculine pronouns in my exegesis, but not otherwise, in order to accurately record the idiom employed in the texts, and this as a reminder that the tradition generally failed until recently to insist on the moral equality of women.

${ }_{67}$ Locke 1689b, Treatises, II $\$ 77$.
} 
So on Locke's own account of the de-facto obligations of necessity that bind employees to employers, it appears that relations between employees and employers do not belong easily to either set (a) or to set (b). Recall that under set (a) the terms and conditions of the power are a matter of convention as between the parties (agreement), and their legitimacy depends upon both parties having given their consent; and under set (b) the power occurs naturally, it is justified by natural law so long as its proper limits are respected, and it may be exercised without the consent of those who must obey it.

Although particular employment relationships are allocated by Locke to set (a), his description of how an individual employee stands vis-à-vis the class of employers reveals that-absent ad hoc countervailing legal or other factors-employees are de-facto embedded in systematically manipulative social relationships, in which they are the manipulanda. Set (a) envisages consensual relations between persons characterized by a meaningful opportunity to give or withhold consent, which promotes mutual respect for moral equality. If set (a) were used as a filter through which to see the employment relationship, it would mislead us as to the empirical nature of employer power.

Further, given the obligations of necessity under which Employee $x$ labors, set (a) is a morally misleading way of seeing the particular, bilateral relations between Employee $x$ and Employer $y$. As I will argue below, the nominal juridical equality of the parties obscures how Employee $x$ 's moral equality may be denied systematically in relations with Employer $y$, absent ad hoc countervailing legal or other factors. Indeed, in response to bitter experience, socialists and social democrats fought for, and attained, some scope for the exertion of countervailing power through (strictly controlled) collective bargaining and piecemeal legal 'regulation' of aspects of the relationship (eg, dismissal). Although those measures may sometimes substantially ameliorate employees' experience of employer power-and, in such cases, have significant moral value - it is important to recognize their limitations as well as how they differ from Rule of Law constitutionalism. I briefly outline such differences in Sections 1 and $5 .{ }^{68}$

Despite the potentially misleading nature of juridical equality as embodied in the formal, contractual features of relations between Employee $x$ and Employer $y$, those properties of the employment relationship are not simply irrelevant. They are real features of the systematization and reconceptualization of characteristically modern forms of power. A hallmark of the transition from feudalism is the fact that now obligations of necessity arise de facto and do not affect the de jure equality of the subordinate party. This innovation is partly captured by set (a)'s way of seeing power. It would be obscured if the employment relationship were ascribed to set (b), as would the genuine moral progress entailed in the abolition of the de jure economic obligations of feudalism.

Indeed, one might say that Locke's prohibition of slavery and vassaldom represents, in effect, the imposition of a measure of limited government on economic power: he implies that relations between economic superiors and inferiors cannot legitimately be constituted so as to confer certain kinds of power on the former. Locke rules out, as contrary to natural law, certain modes of rule over the economically weak that the economically strong might be able to get away with as a matter of their sheer effective power.

Finally, the employment relationship cannot fit into set (c), which contemplates 'just' slavery in certain circumstances: the relevant kind of slave may only be enslaved because of some unjust conduct on his part, which would not obviously apply to employees in general. ${ }^{69}$

\footnotetext{
68 They are also addressed in [ $]$.

69 Though a nuance is added by Macpherson: 'If men are by nature equally rational, in the sense of equally capable of looking after themselves [as Locke holds], those who have fallen permanently behind in the pursuit of property can be assumed to have only themselves to blame': Macpherson 1962, p. 245.
} 
The sets just described are the filters presented to us by Locke's theory as sound ways of seeing and evaluating power. ${ }^{70}$ However, once we reflect on the incipient employer power that Locke himself describes, it becomes apparent that they are inadequate. Because of this inadequacy, Locke is caught on the horns of a dilemma. Assuming a new set is not to be added to (a), (b), and (c), either he maintains, implausibly, that set (a) represents an adequate way of seeing the employment relationship. Or, alternatively, he allocates the relation to set (b) or set (c), which would see employees reduced to the same status as children (whom parents may govern without the children's consent subject to natural law) or to the same status as the justly enslaved (whom masters may govern without the slave's consent because the slave has committed an injustice). But Locke goes out of his way to distinguish employees from children as well as from all kinds of slave. ${ }^{71}$ Each such alternative to set (a) is unpalatable for Locke. ${ }^{72}$

The awkwardness in Locke's account arises because of the particular ways of seeing power he contrives in order to keep ownership and government apart and thereby break with the feudal concept of dominium. Although dominium is inadequate to the modern facts of power-empirically and normatively - so too are Locke's ways of seeing power. Why, then, would Locke choose the particular ways of seeing power that he did?

It seems that Locke has two principal reasons for doing so. The first reason is connected with how he chooses to make his case against absolutism. The second reason stems from Locke's desire to secure protection in favor of property owners (A) from jurisdictional power and (B) for their economic power over others. As I show below, Locke combines his attack on political absolutism with his defence of economic power by holding:

(i) that it is not impermissible for employers to exploit the economic dependence of employees in order to secure the obedience of the latter, subject to certain constraints;

(ii) that such exploitation does not deny the moral equality of employees; and

(iii) that, by contrast, it is impermissible for a pretender to jurisdictional power to exploit the dependence of economic dependents in order to secure the latter's submission; legitimate jurisdictional power must be based on genuine consent.

Why (iii)? Moral equality is disrespected where genuine consent is not forthcoming, where the assent of those under jurisdictional power is secured manipulatively. But then, how to self-consistently maintain commitment (i), and why? Where does (i) leave the moral equality of employees in their relations with employers? As I will now show, Locke's position is an awkward one.

\section{Moral equality and economic power in the employment relationship}

A postulate of Locke's theory is that all men naturally enjoy equal liberty: men owe no natural duties of obedience to any other adult. ${ }^{73}$ It will be recalled that this is the second

\footnotetext{
70 According to Tully, Locke holds 'that our ideas, and so our language, are descriptive and normative and that, with respect to world which men make, our ideas enjoy archetypal priority': Tully 1980, pp. 23-24.

${ }^{71}$ Locke 1689b, Treatises, I \$42, 43; II \$\$ 24, 77, 85, 86, 87.

72 Among other things, this is because Locke seeks to present all adults, including servants, as beneficiaries of juridical equality, which is a status not enjoyed by children or slaves.

${ }_{73}$ Pace Filmer: ibid. Locke begins Chapter II of the Second Treatise by declaring that: 'To understand Political Power right ... we must consider what State all Men are naturally in, and that is, a State of perfect Freedom to order their Actions, and dispose of their Possessions, and Persons as they think fit, within the bounds of the Law of Nature, without asking leave, or depending upon the Will of any other Man. A State also of Equality,
} 
axiom of the fourfold idea of moral equality. ${ }^{74}$ In the state of nature, ex hypothesi, no man has jurisdictional power over any other. ${ }^{75}$ The state of nature is only exited when men establish a binding jurisdictional power. Locke aims to safeguard equal liberty by stipulating that the legitimacy of jurisdictional power depends upon its receiving the unanimous, free, and rational ${ }^{76}$ consent of all individuals. Unanimity is required for the sake of upholding equality liberty without exception.

Locke can claim that men have a natural 'freedom from absolute, arbitrary power', both because of how he limits the scope of valid consent and because of his rejection of the idea of natural jurisdictional power. ${ }^{77}$ Locke's concept of consent is complex, ${ }^{78}$ and there is not space here to do it justice. For present purposes the following outline should be sufficient. For a man's consent to be valid, for it to count towards the maintenance of legitimate jurisdictional power, certain conditions must be satisfied. Locke holds that there are certain things to which men may not validly consent. ${ }^{79}$ For apparent consent to be valid it must be recognizable as an expression of freedom, which Locke understands thus: an individual must (i) know his real interests, (ii) possess the opportunity to act in those interests, and (iii) be disposed so to act. ${ }^{80}$ And an individual's real interests include ensuring that other individuals respect his moral equality.

Assent will therefore not count as valid consent if it is not a true expression of freedom, say because someone purports to consent to slavery, or to its equivalent in connection with state power, which is rule by an 'absolute, arbitrary' jurisdictional power. Such an individual is deemed not to know, and to be disposed to act, in his real interests. Consent will also be vitiated where economic or physical coercion prevents an individual giving or withholding consent according to his real interests. Locke emphasizes that absolutists deny the necessity of free consent, and in doing so reveal their belief that the subjects of the powerful 'were made' for their 'uses, as the inferior ranks of Creatures are for ours'. ${ }^{81}$

Locke observes that a holder of superior economic power could exploit men's economic dependence to the end that they acquiesce in a bid for jurisdictional power. Having noticed that possibility, Locke takes a strong stand against the exploitation of economic power. Such exploitation is condemnable because it does not respect moral equality. He makes this point to combat Sir Robert Filmer's suggestion that jurisdictional power is founded on a superior claim to ownership. The latter argues that, 'God gave the

wherein all the Power and Jurisdiction is reciprocal, no one having more than another...': ibid II \$4. Emphasis in original. And in The Conduct of the Understanding, Locke says that 'all men are naturally equal' (1706) III, 283 cited in Tully 1980, p. 59.

74. See [ $]$; and [] .

${ }^{75}$ Locke $1689 \mathrm{~b}$, Treatises, II $\$ 22$.

${ }^{76}$ Locke distinguishes between two senses of rationality. The first entails seeing the law of nature and trying to comply with it. The second involves applying knowledge to the goal of increased efficacy: Taylor 1989, p. 239. For present purposes, the first requires emphasis.

${ }_{77}$ Locke 1689b, Treatises, II \$23.

${ }^{78}$ Although they broadly share a conception of moral equality, there are important differences between Kant and Locke on the role of consent: Ripstein 2009, ch 7, pp. 182-231.

${ }^{79}$ Locke 1689b, Treatises, II \$23.

80 Bhaskar, 2010, pp. 89-90. This is the conception of freedom that Roy Bhaskar attributes to Karl Marx. Surprisingly, perhaps, it fits well with Locke's conception of freedom in the relevant context: Locke 1689b, Treatises, II \$\$ 4,6, 57: 'Free consent', in Locke's words, is not merely untainted by fraud or coercion, it is also 'the direction of a free and intelligent agent to his proper interest' (ibid II \$57). See also Locke 1689a, Essay, bk IV, ch XX, concerning the importance of knowledge.

81 ' $[\mathrm{B}]$ eing furnished with like Faculties, sharing all in one Community of Nature, there cannot be supposed any such Subordination among us, that may Authorize us to destroy one another, as if we were made for one anothers uses, as the inferior ranks of Creatures are for ours....[or] unless it be to do Justice on an Offender, take away, or impair the life, or what tends to the Preservation of the Life, the Liberty, Health, Limb or Goods of another': Locke 1689b, Treatises, II \$6. Emphasis added. 
world and its resources ... not to all men, but to Adam and his line by natural inheritance'. ${ }^{82}$ As the Stuart line descended from Adam's, according to Filmer, the Stuart monarchy enjoyed Adam's dominion. 'God gave the world originally to ... a particular man as private property. ${ }^{83}$

In combatting Filmer, Locke makes sweeping pronouncements regarding equal liberty, whose implications would seem to reach beyond the state context. The far-reaching nature of those pronouncements, together with his attack on the exploitation of economic power, place him in a very delicate position. He must finesse three elements that threaten to undermine the social vision within which his version of the Rule of Law is to be integrated: see 4.1-4.3 below. Locke's social vision relevantly entails:

(i) respect for moral equality in the establishment and maintenance of jurisdictional power; and

(ii) the preservation of the economic power of employers over employees, ${ }^{84}$ subject to the constraints imposed by:

(a) the contractual framework and juridical equality; and

(b) the prohibition of unjust slavery and vassaldom.

\subsection{The first element: Locke must describe and condemn the exploitation of economic power by a pretender to jurisdictional power}

For the sake of his vision, Locke must describe and condemn the exploitation of economic power by a pretender to jurisdictional power. In the First Treatise, Locke describes how a man with substantial property might bend an economic inferior to his will, and also how he might exert the same power over a whole community if it is sufficiently dependent on him:

... how will it appear, that Property in Land gives a Man Power over the Life of another? Or how will the Possession even of the whole Earth give any one a Soveraign Arbitrary Authority over the Persons of Men? The most specious thing to be said, is, that he that is Proprietor of the whole World, may deny all the rest of Mankind Food, and so at his pleasure starve them, if they will not acknowledge his Soveraignty, and Obey his Will. ${ }^{85}$

It may at first seem that, according to Locke, natural property rights cannot properly include the power to exploit others' dependence on the resources that one controls, including for the sake of securing the service of Employee $x{ }^{86}$ This impression is reinforced by $\$ 42$ of the First Treatise:

$[\mathrm{N}]$ o Man could ever have a just Power over the Life of another, by Right of property in Land or Possessions ... a Man can no more justly make use of another's necessity, to force him to become his Vassal, ... than he that has

\footnotetext{
82 As summarized by Waldron 1988, p. 144.

83 Ibid p. 148.

${ }^{84}$ For a related discussion, see Macpherson 1962, pp. 245-246.

${ }^{85}$ Locke 1689b, Treatises, I \$41.

86 Which is Tully's reading: Tully 1980, p. 137. For persuasive cases to the contrary, Wood 1984, pp. 85-92; Waldron 1988, pp. 144-148, 225-232; Cohen 1999, p. 164, note 7.
} 
more strength can seize upon a weaker, master him to his Obedience, and with a Dagger at his Throat offer him Death or Slavery. ${ }^{87}$

However, it is important to recall Locke's commitments and his objectives. He does not say that no man should have so much wealth that they would have the potential to exercise such power: his theory of property rules out such a prohibition. ${ }^{88}$ What he does say is that such power should never be exercised for the end of maintaining 'Soveraign Arbitrary Authority over the Persons of Men'; that is, never for the end of maintaining jurisdictional power.

Locke does not say that a man cannot 'justly make use of another's necessity, to force him to become his' employee. Locke only prohibits such 'force' in connection with vassaldom, a relationship of pre-modern dominium. Nor does Locke say that the employment relationship must be legally constituted in a manner designed to prevent power being exercised 'arbitrarily' in the limited government sense. By contrast with his stance in respect of jurisdictional power, he does not insist on a relationship between law, employer power, and interests, expectations, and rights that is systematically conducive to respect for moral equality and therefore promotes freedom as he understands it. Put differently, he does not insist on the Rule of Law in connection with employer power.

\subsection{The second element: Locke must ensure that his condemnation of economic exploitation on the part of state power does not require him to condemn it on the part of an employer}

Locke must ensure that his condemnation of the 'use of another's necessity' by a would-be holder of jurisdictional power in $\$ 42$ does not commit him to a condemnation of the use of employees' dependence by employers. He attempts to do this in \$43-with his next breath, so to speak-by deeming the relation between Employee $x$ and Employer $y$ to be one characterized by reciprocal respect for equal liberty. The evidence for this, according to Locke, is the fact that the relation is formally treated as a matter of convention (agreement), which confers no more power on the employer than the employee has agreed:

since the Authority of the Rich Proprietor, and the Subjection of the Needy Beggar, began not from the Possession of the Lord, but the Consent of the poor Man, who preferr'd being his Subject to starving. And the Man he thus submits to, can pretend to no more Power over him, than he has consented to, upon Compact. ${ }^{89}$

Recall $\$ 85$ of the Second Treatise, ${ }^{90}$ where Locke describes the requirements and incidents of juridical equality between employer and employee in strikingly modern terms. ${ }^{91}$

But why couldn't an economic superior who purports to maintain jurisdictional power upon the basis of the 'use of another's necessity' adopt an equivalent deeming strategy in order to say that it too has not violated equal liberty? 92

\footnotetext{
${ }^{87}$ Locke $1689 b$, Treatises, I $\$ 42$.

88 ibid II $\$ \$ 46,48$.

${ }^{89}$ Ibid I $\$ 43$. That this amounts to a genuine 'compact' is implausible by Locke's own lights, which he sets out when discussing the quality of consent required in respect of jurisdictional power: see the main text at note 48 above.

90 See main text above at $\mathrm{n} 43$.

91 This could be seen as another example of Locke's tendency, as observed by Macpherson, to read back into the state of nature conditions of power belonging to the modern world: Macpherson 1962; Locke 1689b, Treatises, II $\$ 14$.

${ }^{92}$ See quotation in the main text at note 48 above (esp. 'Nor does it alter the case to say, I gave my promise...').
} 

condemnable features of unjust slavery or vassaldom

In seeking to establish the legitimacy of the employment relationship, Locke is careful to ensure that it is not seen as sharing those features of unjust slavery or vassaldom which he considers condemnable. Locke's attack on dominium and, in turn, on Filmer's position, commits him to the condemnation of slavery and vassaldom as they too involve a claim to combined ownership and jurisdiction. ${ }^{93}$ Locke insists that the employment relationship is distinguished from slavery and vassaldom insofar as Employee $x$ may be subject to the power of Employer $y$ without the former forfeiting his juridical equality with the latter.

This reading is reinforced by Locke's conception of just slavery (which it will be recalled belongs to set (c): see Section 2.1 above). Locke defines the justly enslaved as:

another sort of servants, which be a peculiar name we call slaves, who, being captives taken in a just war, are by the right of nature subjected to the absolute dominion and arbitrary power of their employers. ${ }^{94}$

This is in effect a special context in which Locke recognizes that legitimate jurisdictional power, as he sees it, may be maintained without the consent of the ruled and carried on without the constraints of limited government. ${ }^{95}$

However, just slavery is not founded on the exploitation of economic superiority. Locke held that slavery arrived at through such exploitation constitutes an inherently improper relationship because it purports to maintain jurisdictional power by exclusive reliance on such exploitation: Locke condemns the exploitation of economic dependence if it is used to maintain jurisdictional power.

Further, for Locke it is apparently the 'natural and unalterable state of things' 96 that economic superiors will dehumanize juridically free employees:

It is not to be expected that a man, who drudges on all his life in a laborious trade, should be more knowing in the variety of things done in the world than a packhorse, who is driven constantly forwards and backwards in a narrow lane and dirty road only to market, should be skilled in the geography of the country. ${ }^{97}$

Locke here notices that employees are sometimes treated as though they had the moral status of instruments or beasts of burden. His reference to 'the Inferior Creatures' in $\$ 92$ of the First Treatise, in his description of the ends of property, is therefore significant:

Property, whose Original is from the Right a Man has to use any of the Inferior Creatures, for the Subsistence and Comfort of his Life, is for the benefit and sole Advantage of the Proprietor, so that he may even destroy the thing ... but Government being for the Preservation of every Mans Right and Property, ... is for the good of the Governed ... the Sword is not given the Magistrate for his own good alone. ${ }^{98}$

\footnotetext{
${ }^{93}$ Locke 1689b, Treatises, II \$ 23; Waldron 1988, p. 227.

${ }^{94}$ Locke 1689b, Treatises, II $\$ 85$.

${ }_{95}$ On just enslavement, ibid II \$24.

${ }^{96}$ Locke quoted in Waldron 1988, p. 229.

${ }_{97}$ Locke 1689a, Essay, bk IV, ch XX \$2; this passage is used to criticize Tully's reading in Waldron 1988, p. 229.

${ }_{98}$ Locke 1689b, Treatises, I \$92.
} 
Of course, Locke's prohibition on unjust slavery means that a master cannot use an employee in just the same way as 'any of the Inferior Creatures ... so that he may even destroy the thing. ${ }^{99}$

Nonetheless, when it comes to the establishment and exercise of employer power, Locke is no longer rigorous in his identification and condemnation of threats to moral equality. He considers it unexceptionable that concentrated property ownership generates relations of dependence, and that such dependence confers upon employers the power to treat employees' time as morally equivalent to the time belonging to 'Inferior Creatures'. The employee's time may be treated as a mere means 'for the Subsistence and Comfort' of the employer. ${ }^{100}$

Under conditions of severe economic dependence, not only are land, things, and beasts 'for the benefit and sole Advantage of the Proprietor', but so is the labour time of people who have no effective power to refuse to sell it as an instrument to be applied to the buyer's ends:

I confess, we find among the Jews, as well as other Nations, that Men did sell themselves; but, 'tis plain, this was only to Drudgery, not to Slavery. ${ }^{101}$

While Locke's prohibition on slavery means that a person's life cannot be bought and sold, practically all of an employee's life time can be bought, to be used up as though it were property, ${ }^{102}$ like the time of the 'packhorse, who is driven constantly forwards and backwards in a narrow lane and dirty road only to market'.

Of course, one might seek to show that an employer's power to consign an employee to 'Drudgery' and the life of a 'packhorse' is not for the 'sole Advantage' of the employer. Perhaps such an existence is best understood, to the contrary, as being in both parties' interests and for 'the good of the Society', ${ }^{103}$ on the assumption that everyone is thereby made richer than they would otherwise be. ${ }^{104}$ And, if so, then perhaps consent to the modern

\footnotetext{
99 Ibid.

100 Consider in this light, the remarks of Finnis: 'the reason why the Rule of Law is a virtue of human interaction and community' is that people should not be 'made to live their lives for the convenience of others': Finnis 2011 , p. 272.

${ }^{101}$ Locke $1689 \mathrm{~b}$, Treatises, II $\$ 24$.

${ }^{102}$ Hence the lamentable truth inadvertently conveyed the contemporary notion of 'work-life balance': one's work and life may only be balanced one against the other if one experiences work as separate from one's life, perhaps because the sale of a portion of one's time to another feels like a subtraction of a portion of one's life. ${ }^{103}$ Locke 1689b, Treatises, II § 137.

${ }_{104}$ Perhaps a defender of Locke's scheme would attempt a strategy resembling that which is called in aid of Locke's theory of property. On Leo Strauss's reading, Locke would claim that:
}

The day laborer in England has no natural right even to complain about the loss of his natural right to appropriate land and other things by his labor: the exercise of all the rights and privileges of the state of nature would give him less wealth than he gets by receiving "subsistence" wages for his work. Far from being straitened by the emancipation of acquisitiveness, the poor are enriched by it. For the emancipation of acquisitiveness is not merely compatible with general plenty, but is the cause of it. Unlimited appropriation without concern for the need of others is true charity.

Strauss 1952, p. 495. In addition to the advent of money in the state of nature (e.g., 1689b, Treatises, II $\$ 50$ ), Locke seems to rely, in substance, on what we would now call the 'trickle down theory' to overcome the natural law limitations of his famous 'enough and as good' or 'sufficiency' proviso: ibid II $\$ 37$; II $\$ 41$. Discussed in Macpherson 1962, pp. 197-221. Consider Richard Posner's remarks, 'Only the fanatic refuses to trade off lives for property...': Posner 1983, pp. 83-84. But whose lives? For whose property? How to ensure that those with the power to determine the allocation of benefits and burdens do not deny the moral equality of those who would suffer the burdens? On benefits and burdens and Immanuel Kant, see Ripstein 2009 , p. 5. 
constitution of employer power would represent 'the direction of a free and intelligent agent to his proper interest'. ${ }^{105}$

In the centuries following Locke's death, defenders of the capitalist employment relationship have attempted arguments along the lines just described. There is not space here to consider the merits of even the most meritorious of such arguments. Nonetheless, the limited government tradition's own experience provides a reason to sound a note of caution. For all of their sophistication - or perhaps in part because of it - such arguments recall the very object of the Two Treatises' devastating critique: the ingenuity of the defenders of princely power whose sophistry Locke sought to expose. What if defenders of a certain political constitution were to claim that the constitution legitimately permits rulers to drive subjects like packhorses, because the subjects appear to have consented and are said to be richer than they would be without the rulers' regime? The Treatises leave no doubt as to how a true Lockean should respond: any purported consent would be invalid in light of the considerations outlined at the start of this Section. Where an equivalent claim is made by defenders of the present constitution of economic power, we need to be more Lockean than Locke: when evaluating such claims, we must be no less skeptical, demanding and exacting than we would be when dealing with state power. We need also to consider that the nature of an employee's moral stake in work extends far beyond an interest in having more and better things. ${ }^{106}$

\subsection{Summation}

In sum, Locke treats the exploitation of economic weakness as morally reprehensible when it is undertaken on the part of jurisdictional power. He likens it to a man who has more strength' seizing 'upon a weaker' and 'with a Dagger at his Throat' offering him 'Death or Slavery'. He insists that 'a Man can no more justly make use of another's necessity, to force him to become his Vassal'. ${ }^{107}$ If a state, having been established in that manner, then drove its people 'constantly forwards and backwards' like packhorses, Locke would readily condemn such treatment as 'arbitrary' and the constitution as 'tyrannical'.

Implicit in such condemnation would be the claim that the rulers had failed to give due weight to: (i) the basic right of persons not to be confronted with a choice between assent to tyrannical rule or an even worse fate; and (ii) the basic right of persons to have their moral equality respected, which includes having their full worth as humans recognized by the protection of their 'lives, liberties, and estates' from unreasonable incursions by state power. ${ }^{108}$ However, when Locke turns his attention to the employment context, he claims that 'the Authority of the Rich Proprietor' is legitimately derived from 'the Consent of the poor Man, who preferr'd being his Subject to starving'. ${ }^{109}$ In the jurisdictional setting, such circumstances would vitiate consent.

Further, Locke assures his readers that the employer 'can pretend to no more Power over' the employee than the latter 'has consented to, upon Compact'. ${ }^{110}$ But he also readily accepts that, in reality, such a 'Compact' could consign - and perhaps often does consignthe employee to 'Drudgery' and to the status of a 'packhorse'. The contents of the employment compact appear to be a matter of what the 'Rich Proprietor' can get away with, and his power is subject to no a priori-constitutional-limits (except, perhaps, for the prohibitions on slavery and vassaldom: see Section 3 above).

\footnotetext{
${ }^{105}$ Locke 1689 b, Treatises, II $\$ 57$.

106 Compare the implicit view attributed to Locke by Strauss at note 104.

${ }_{107}$ Locke 1689b, Treatises, I \$42.

108 Ibid II \$123.

109 Ibid I \$43.

110 Ibid I $\$ 43$.
} 
By contrast, the people, when deliberating in the state of nature, could not validly consent to a 'Compact' which would have them abnegate their equal worth by sinking to the status of packhorses under the whip of state power: for Locke, this would be an unacceptable renunciation of their 'lives, liberties, and estates', and they would be better off remaining in the state of nature. The would-be 'Compact' in question would be void at the outset due to its failure to limit government for the sake of the people's respect-worthy interests, expectations, and rights.

The early socialists refused to accept such normative contortions. They appropriated the idiom of slavery - and in turn the rhetorical resonance it had acquired in political thought ${ }^{11}$ - in order to condemn the moral inequality embodied in the modern wagerelation. This condemnation is expressed in the concept of 'wage slavery'. 'Wage slavery', as a filter for seeing and evaluating power, represents an alternative to Locke's way of seeing the employment relationship. It is presented by socialists as belonging outside the sets of permissible power over others. It is a type of impermissible power over others. Locke, by contrast, refuses to ask whether the employment relationship's constitution jeopardizes moral equality by being hospitable to the arbitrary exercise of power.

\section{Conclusion}

I have contended that Locke defined the scope of the limited government tradition's inquiries too narrowly. In doing so he misdirected the tradition's adherents, obscuring their moral obligation to grapple with the implications of economic power. Given Locke's immense influence on the subsequent development of the tradition, it is reasonable to ascribe to Locke a prominent, though not exclusive, place in any account of the persistence of this oversight.

As a result of Locke's virtual silence in the face of the challenge posed by economic power, he leaves himself vulnerable to precisely the kind of objection that was at the heart of his condemnation of the absolutists. Locke contends that without his doctrine of limited government, the potential gains of our departure from the mischiefs of the state of nature are likely to be thwarted by the arbitrary exercise of illegitimate jurisdictional power. According to Locke, the absolutists' failure to see this implied that:

... Men are so foolish that they take care to avoid what Mischiefs may be done them by Pole-Cats, or Foxes, but are content, nay think it Safety, to be devoured by Lions. ${ }^{112}$

I would argue that Locke's failure to give due attention to economic power is the same kind of oversight. His own observations, firstly about the potency of economic power, and secondly about the moral imperatives underlying the limited government project, make the omission particularly grave. Locke's oversight has been inherited by the modern limited government tradition that he helped to found: it has failed to live up to its own principles by its systematic failure to see the power of economic 'Lions' as a source of limited government questions.

In this Article, I have explored Locke's contribution to a distinctively modern way of seeing power. Central to this way of seeing is a particular manner of separating ownership and jurisdiction. That separation lends unjustified plausibility to the supposition that only state institutions exercise the kind of power over others that should arouse the suspicion of proponents of the limited government tradition's Rule of Law vision.

\footnotetext{
${ }^{111}$ Skinner 1998, pp. 39-50.

${ }^{112}$ Locke 1689b, Treatises, II \$93.
} 
I have shown that when Locke's own descriptive portrait of employer power is seen in the light of his normative account of the tradition's underlying principles, the system of power which he describes seems to offend those principles. Despite this, Locke implies that modern employer power is straightforwardly compatible with his limited government vision, and, in doing so, effectively prescinds such power from the tradition's Rule of Law project. These ways of seeing power, and of defining the tradition's project, are broadly shared by liberal public philosophy. In consequence, employer power-along with other incidents of the power conferred by economic dependence-are treated as matters to be dealt with by other mechanisms.

The most widely favored set of mechanisms is sometimes referred to as 'regulation'. As discussed in Section 1, the modern regulatory project operates through ad hoc restraints. It is premised on the notion that 'private' persons are entitled to do as they please, save insofar as they are restrained by positive law: in the case of private subjects, it is a principle of law-indeed, a constitutional principle-that everything that is not prohibited is permitted, which is not the case for public officials. ${ }^{13}$ However, when private actors wield power over others and moral equality is at stake-as in the case of employer power-it is doubtful whether the principle is sound. Nonetheless, unlike the Rule of Law project, regulation seeks neither to eradicate, nor even to de-legitimize as such, manipulative, nonstate social relations by reconstituting them along anti-manipulative lines. The fragmentary nature of regulation reflects a tacit acceptance that the exploitation of economic weakness will be an organizing principle of economic life subject only to the ad hoc limits imposed by individual regulations, if any. It envisages that in certain contexts, as determined from time to time and on a case-by-case basis, the law will impose limits to prevent 'excesses'.

The regulatory project accepts, for example, that 'private economic activity knows but one general principle, that of obtaining a maximum return from limited resources', ${ }^{114}$ even where the resources are human. Far from prohibiting manipulative social relationships, the exclusive pursuit of this principle positively encourages them. And, as Lon Fuller points out, the principle remains in force and is not fundamentally de-legitimized:

even when the restraints surrounding economic calculation are expanded to include, let us say, the obligation to pay a minimum wage, to provide some form of job security, and to submit discharges to arbitration. Obligations like these serve simply to shrink the framework within which economic calculation takes place; they do not change the essential nature of that calculation. ${ }^{115}$

The Rule of Law, by contrast, seeks to reconstitute the very nature of a given form of power by comprehensively subjecting the decisions of relevant officials to systematic legal accountability mechanisms for the sake of safeguarding moral equality. As the judicial dicta quoted in the Introduction demonstrate, the Rule of Law's ambition is to humanize the 'essential nature' of all calculations made by relevant state officials.

As I have shown, there are persuasive limited government reasons for asking whether employer power should be reconstituted according to the tradition's Rule of Law vision. Such reconstitution would involve the deliberate redesign of employer power so that its holders would be legally obliged to exercise it in non-arbitrary ways-ways that uphold moral equality for all and freedom for all from manipulative social relationships. Such a legal obligation would not be confined to 'regulating' certain contexts, such as the context

\footnotetext{
113 This distinction is explained, with approval, by Sir John Laws, Laws 1997, p. 466.

${ }_{114}$ Fuller c1969, p. 171.

115 Ibid.
} 
of dismissal. Instead, it would apply comprehensively, in respect of every instance of the exercise of employer power.

The question whether the employment relationship ought to be reconstituted along limited government lines raises complex issues. After a searching inquiry, one might determine that there are compelling reasons not to take that path. But there are no good reasons not to pose the question. And given that moral equality is at stake, the justification for a negative response to the question needs to be persuasively articulated rather than presupposed. This Article has not attempted to answer the question. Rather, it has contributed to 'clearing the ground a little', to borrow a phrase from Locke. ${ }^{116}$ It has done so by raising doubts about the state axiom whose entrenchment Locke furthered.

The modern Rule of Law lens that Locke helped to craft obscures the power conferred by private ownership. The only types of power we tend to see are those that the state has monopolized de jure. They are the types of power we would now call 'political' or 'jurisdictional' power, such as the powers to arrest, imprison, or seize property. Today, the Leviathan fills our field of vision. The influence of this way of seeing blinds the limited government tradition to the potentially arbitrary nature of the power wielded by property owners. The failure to see economic power as a source of limited government questions is a defect in Locke's theory and in the liberal Rule of Law project Locke helped to shape.

\section{References}

Allan TRS (2003) Constitutional justice: A liberal theory of the rule of law. Oxford University Press, Oxford

Allan TRS (2013) The sovereignty of law: Freedom, constitution and common law. Oxford University Press, Oxford

Allen v Flood [1898] AC 1

Arendt H (1999) The human condition. 2nd edition, University of Chicago Press

Avineri S (1968) The social \& political thought of Karl Marx. Cambridge University Press, London

Berlin I (1958) Two concepts of liberty. In: Hardy H (ed) (2002), Liberty: Incorporating four essays on liberty. Oxford University Press, Oxford, pp. 166-2 17

Bhaskar R (2011) Reclaiming reality: A critical introduction to contemporary philosophy. Routledge, London

Berman HJ (1983) Law and revolution. Harvard University Press, Cambridge, MA

Blades LE (1967) Employment at Will vs. Individual Freedom: On limiting the abusive exercise of employer power. Columbia Law Review 67: 1404-1435

Board of Regents v Roth 408 US 564 (1972)

Cohen GA (2001) Paradoxes of conviction. In: If you're an egalitarian, how come you're so rich? Harvard University Press, Cambridge MA, pp. 7-19

Cohen J (1999) Structure, choice, and legitimacy: Locke's theory of the State. In: Morris CW (ed), The social contract theorists: Critical essays on Hobbes, Locke, and Rousseau. Rowman \& Littlefield, Lanham, Md, pp 143-166

Dworkin R (1996) Freedom's law: the moral reading of the American constitution. Oxford University Press, Oxford

Dworkin R (1998) Law's empire. Hart, Oxford

Dworkin R (1985) A matter of principle. Harvard University Press, Cambridge, MA

116 Epistle to the reader. In: Locke 1689a, pp 6-14. Emphasis added. 
Endicott T (2013) The irony of law. In: Keown J, George RP (eds), Reason, morality, and law: The philosophy of John Finnis. Oxford University Press, Oxford, pp 327-345

Farr J (1986) "So vile and miserable an estate": The problem of slavery in Locke's political thought. Political Theory 14: 263-289

Federated Engine-Drivers and Firemen's Association of Australasia v The Broken Hill Pty Co Ltd (1911) 5 CAR 9

Finnis J (2011) Natural law \& natural rights, 2nd edn. Oxford University Press, Oxford Fuller L (c1969) The morality of law. Yale University Press, New Haven

Garrett v AG [1997] 2 NZLR 332

Goodhart AL (1958) Rule of law and absolute sovereignty. U Pa L Rev 106: 943-963

Hamilton A (1788) The Federalist No. 84. In: Hamilton A, Madison J and Jay J. The

Federalist: With letters of Brutus. In: Ball T (ed) (2003), Cambridge texts in the history of political thought: The federalist: With letters of Brutus. Cambridge University Press, Cambridge

Hayek FA (1960) The constitution of liberty. Routledge and Kegan Paul, London

Joint Anti-Fascist Refugee Committee v McGrath 341 US 123 (1951)

Jones v Swansea City Council [1989] 3 All ER 162

Kahn-Freund O (1949) Introduction. In: Renner K, Kahn Freund O (ed), Schwarzschild O

(trans) (1976) The institutions of private law and their social functions. Routledge

and Kegan Paul, London, pp 1-43

Laws J (1997) Public law and employment law: Abuse of power. Public Law: 455-466

Locke J (1689a) An essay concerning human understanding. Nidditch PH (ed) (1975)

Clarendon Press, Oxford

Locke $\mathbf{J}(1695)$ The reasonableness of Christianity: As delivered in the scriptures. HigginsBiddle JC (ed.) (2000) Oxford University Press, USA

Locke J (1689b). Two treatises of government. J Locke, London

Macpherson CB (1962) The political theory of possessive individualism: Hobbes to Locke.

Oxford University Press, London

Marx K (1894) Capital: A critique of political economy. Volume III. Fernbach D (trans) (1991). Penguin Books, London

McDowell GL (2010) The language of law and the foundations of American constitutionalism. Cambridge University Press, Cambridge

Mill JS (1879) Chapters on socialism. In: Collini S (ed) (1989) On Liberty and other writings. Cambridge University Press, Cambridge, pp. $219-280$

Milsom SFC (1969) Historical foundations of the common law. Butterworths, London

Payne v Western \& Atlantic Railroad 81 Tenn 507 (1884)

Pollock F (1922) Essays in the law. Macmillan, London

Posner R (1983) The economics of justice. Harvard University Press, USA

Ripstein A (2004) Authority and Coercion. Philosophy \& Public Affairs 32: 2-35

Ripstein A (2009) Force and freedom: Kant's legal and political philosophy. Harvard University Press, Cambridge, MA

Rousseau J-J (1762) The social contract and other later political writings. Gourevitch V (ed, trans) (1997). Cambridge University Press, Cambridge

Sandel M (1998) Democracy's discontent: America in search of a public philosophy. Belknap Press of Harvard University Press, Cambridge, MA

Schachtman v Dulles 225 F2d 938 (DC Cir 1955)

Schuyler R (ed), (1960) Interpretation of Anglo-Saxon land books and charters. In: Frederic William Maitland historian: Selections from his writings. University of California Press, Berkeley, pp 145-172

Sidney A (1989) Discourses Concerning Government. Liberty Fund Inc

Skinner Q (1978) The foundations of modern political thought. Cambridge University Press, Cambridge 
Skinner Q (1998) Liberty before liberalism. Cambridge University Press, Cambridge Skinner Q (2002) Visions of politics. Cambridge University Press, Cambridge

Strauss L (1952) On Locke's doctrine of natural right 61 The Philosophical Review 475

Taylor C (1989) Sources of the self: The making of the modern identity. Cambridge University Press, Cambridge

Three Rivers District Council v Governor and Company of the Bank of England (No. 3) [2003] 2 AC 1

Tully J (1980) A discourse on property: John Locke and his adversaries. Cambridge University Press, Cambridge

Union Labor Hospital Association v Vance Redwood Lumber Co 158 Cal 551 (1910)

Wade ECS (1961) Introduction. In: Dicey AV, Introduction to the study of the law of the constitution, $10^{\text {th }}$ edn. Macmillan, London, pp. xix-cxcviii

Waldron J (1988) The right to private property. Oxford University Press, Oxford

Weber M (c1922) Economy and society: An outline of interpretive sociology. Roth G, Wittich C (eds), Fischoff E et al (trans) (1978). University of California Press, Berkeley

Weiler PC (1990) Governing the workplace: The future of labor and employment law. Harvard University Press, Cambridge, MA

Westminster Corporation v London \& North Western Railway [1905] AC 426

Williams Z (7 May 2014) The Guardian, London, England

Wood EM (2008) Citizens to lords: A social history of western political thought from antiquity to the late middle ages. Verso, London

Wood EM (1995) Democracy against capitalism: Renewing historical materialism. Cambridge University Press, Cambridge

Wood N (1984) John Locke and agrarian capitalism. University of California Press, Berkeley

Young K G (2012) Constituting economic and social rights. Oxford University Press, Oxford 